\title{
Saved by the shell: Oyster reefs can shield juvenile blue crabs Callinectes sapidus
}

\author{
Katherine S. Longmire, Rochelle D. Seitz ${ }^{*}$, Alison Smith, Romuald N. Lipcius
}

Virginia Institute of Marine Science, William \& Mary, PO Box 1346, Gloucester Point, Virginia 23062, USA

\begin{abstract}
Juvenile blue crabs Callinectes sapidus use seagrass and other structured habitats as refuges from predation. Oyster reef habitats provide structural complexity that may offer refuge, but the value of these habitats for juvenile blue crabs has not been examined. We quantified survival of juvenile $C$. sapidus in structured oyster reef habitat versus unstructured soft-bottom habitat. In a field tethering experiment in the York River, lower Chesapeake Bay (USA), juvenile $C$. sapidus $(10-50 \mathrm{~mm}$ carapace width [CW]) were tethered in sand $(\mathrm{n}=40)$ or oyster reef $(\mathrm{n}=39)$ habitats at subtidal sites 1-2 m deep. An underwater camera system was used to record predation activity during $24 \mathrm{~h}$ trials. Juvenile crab survival was significantly higher on the oyster reef habitat $(53.8 \%)$ than on bare sand $(15.0 \%)$, and tended to increase with crab CW in both habitats. The main successful predators on juvenile blue crabs were northern pufferfish Sphoeroides maculatus in the oyster reef habitat and adult blue crabs in the sand habitat. The high survival rate of juvenile C. sapidus in oyster reef habitats suggests that oyster reefs include physical habitat complexity that may offer refuge from predators. Restored and natural oyster reefs could provide an alternative nursery habitat for juvenile blue crabs, expanding the ecosystem services provided by restored oyster reefs.
\end{abstract}

KEY WORDS: Blue crab $\cdot$ Tethering $\cdot$ Oyster reef $\cdot$ Habitat refuge $\cdot$ Nursery habitat $\cdot$ Ecosystem services $\cdot$ Chesapeake Bay

\section{INTRODUCTION}

\subsection{Nursery habitat}

Structurally complex habitats can serve as nursery grounds for many invertebrates, including blue crabs Callinectes sapidus. Structured nursery habitats for blue crabs include seagrass beds (Heck \& Thoman 1984, Heck et al. 2003, Lipcius et al. 2005, Seitz et al. 2005, Ralph et al. 2013), non-native algae (Johnston \& Lipcius 2012), salt marshes (Minello et al. 2003), and coarse woody debris (Everett \& Ruiz 1993). Structure can reduce the ability of a predator to find prey (Grabowski 2004), which may be key in reducing predator-prey and cannibalistic interactions of adult and juvenile blue crabs (Moksnes et al. 1997). Blue crab survival is enhanced in structured seagrass

\footnotetext{
*Corresponding author: seitz@vims.edu
}

habitats versus unstructured habitats, like sandy bottom, due to inhibition of predator detection (Wilson et al. 1990, Hovel \& Lipcius 2001, 2002, Seitz \& Ewers Lewis 2018). Oyster reefs provide protection from predation for mud crabs in Gulf Coast systems (Hill \& Weissburg 2013), but their function in providing protection for juvenile blue crabs is unknown. Provision of habitat to increase survival of juvenile blue crabs could be an important ecosystem service of restored oyster reefs and is important to quantify.

\subsection{Prey, predators, and crab size effects}

The blue crab is a large portunid crab that is distributed along the Northwest Atlantic, Gulf of Mexico, and Caribbean coasts (Williams 1984, Lipcius

() The authors 2021. Open Access under Creative Commons by Attribution Licence. Use, distribution and reproduction are unrestricted. Authors and original publication must be credited. 
\& Van Engel 1990) and serves as predator and prey (Lipcius et al. 2007). It supports one of the most important fisheries in Chesapeake Bay (USA), with over $75000 \mathrm{t}$ landed per year, which is worth US\$81 million to the economy (NOAA 2019). This species is also vital ecologically, as it is a key component in the Chesapeake Bay food web (Baird \& Ulanowicz 1989, Lipcius \& Latour 2006). The main predators of juvenile blue crabs typically include conspecifics and epibenthic fishes (Bromilow \& Lipcius 2017). Blue crabs are epibenthic generalists that forage on a wide variety of infaunal and epibenthic invertebrates as well as on plant material (Mansour 1992, Meise \& Stehlik 2003, Stehlik et al. 2004). Ecologically, blue crab foraging has major effects on prey populations and benthic community structure (Hines 2007). The abundance and availability of prey, including eastern oysters (Eggleston 1990a,b,c) and hard clams (Van Engel 1958, Sponaugle \& Lawton 1990), can be limited by blue crab predation. Blue crabs are central to Chesapeake Bay food web models (Baird \& Ulanowicz 1989, Lipcius \& Latour 2006); thus, blue crab predatorprey interactions are key to understanding the Chesapeake Bay ecosystem.

Prey size and habitat complexity are important in a predator-prey relationship. In unvegetated mud habitats, juvenile blue crab survival increases with carapace width (CW) (Johnston \& Lipcius 2012), although the opposite is true in eelgrass habitats, leading to a predation-induced ontogenetic shift in habitats (Lipcius et al. 2007). Moreover, predators in structurally complex habitats are less successful than those in habitats that are not complex (Sih et al. 1985, Stoner 2009). Structurally complex habitats provide spaces and cover (i.e. shells, corals, and plants) in which animals can hide; thus, juvenile blue crabs are able to avoid multiple predators using habitat refuge. Therefore, the interstitial space provided by oyster reefs may serve as a refuge for juvenile blue crabs against predation and cannibalism.

Key components in predator-prey interactions involve aspects of the functional response of a predator, such as encounter time, handling time, and habitat (Holling 1959a,b). Handling time (HT), the time required for a predator to capture and consume prey, typically increases with armored prey (e.g. eastern oyster Crassostrea virginica), thereby reducing consumption rates (Hassell 1978). Time to first encounter, or encounter time (ET), can be defined as the initial predatory interaction between searcher (predator) and prey (Gurarie \& Ovaskainen 2013). The effect of increased HT is typically a quantitative reduction in predation rate allowing local persistence, whereas the effect of a reduced ET is a qualitative shift and decreasing predation rates at low prey densities, resulting in a low-density refuge (Seitz et al. 2001). A predator's ET changes with habitat when structural impediments to predators, such as decreased sediment penetrability (Lipcius \& Hines 1986, Seitz et al. 2001) or increased vegetative cover (Lipcius et al. 1998, Hovel \& Lipcius 2001), result in reduced accessibility of prey to predators. These structural impediments may thus enhance survival from cannibalism and predation (Lipcius \& Hines 1986, Glaspie \& Seitz 2018). Thus, examining ET and HT using field experiments can be insightful to aid further research on the effects of habitat on predator-prey interactions.

\subsection{Ecosystem services of oyster reefs}

Oyster reefs provide abundant ecosystem services, such as habitat and foraging grounds for recreationally and commercially valuable fish (Peterson et al. 2003, Coen \& Grizzle 2007, Pfirrmann \& Seitz 2019). Recently, oyster restoration has been employed not only to enhance oyster abundance but also to enhance production of other species (Peterson et al. 2003, Plunket \& La Peyre 2005, Rodney \& Paynter 2006, Coen et al. 2007). The habitat benefits of oyster reefs have been documented for finfish and some crab species in other ecosystems (Posey et al. 1999, Gregalis et al. 2009), such as in the southeast Atlantic (Meyer \& Townsend 2000, Wilber et al. 2012) and the Gulf of Mexico (Thomas et al. 1990, zu Ermgassen et al. 2021); however, the function of eastern oyster reefs as habitat for blue crabs in Chesapeake Bay remains unknown. Crabs and fish may increase their production on oyster reefs depending on reef characteristics, environmental conditions, and season (Coen \& Grizzle 2007, Gregalis et al. 2009, Robillard et al. 2010, Humphries et al. 2011, Yeager \& Layman 2011). Thus, studies from one system may not necessarily apply to another. Studies from other systems suggest that small crabs, such as mud crabs, prefer oyster reef over vegetated marsh edge or unvegetated habitats, potentially due to the abundance of small refugia (Shervette et al. 2011). However, this preference for oyster-reef habitat over marsh or unvegetated habitats has not been documented for juvenile blue crabs.

Recent studies on restored oyster reefs using settlement trays demonstrated that larger juvenile and adult crabs utilized oyster reefs, but predominantly 
as foraging grounds (Karp et al. 2018). Hence, studies are warranted to determine the role of oyster reefs as potential refuge habitat for juvenile blue crabs.

The objectives of the current study were to (1) examine survival of juvenile blue crabs on oyster habitat versus unstructured sand habitat; (2) determine changes in survival of juvenile crabs with crab size in the 2 habitats; (3) identify predators responsible for crab mortality; and (4) quantify ETs and HTs of different predators. We hypothesized that (1) oyster habitat would increase juvenile blue crab survival; (2) juvenile blue crab survival would increase with crab size; (3) predators of juvenile crabs would differ between oyster and sand habitats; and (4) ETs and HTs would differ significantly among predators.

\section{MATERIALS AND METHODS}

\subsection{Site selection}

This study was conducted in the York River at a subtidal (1-2 m water depth) location near the Virginia Institute of Marine Science (VIMS) in Gloucester Point, VA, from late July through early October 2017. Hydrographic conditions (water temperature, salinity, and dissolved oxygen [DO]) were obtained from a nearby VIMS Virginia Estuarine and Coastal Observing System (VECOS) monitoring buoy at Gloucester Point (CBNERR 2018). Hydrographic data from late July to early October 2017 indicated that water temperature averaged $26.0^{\circ} \mathrm{C}$ and ranged from 22 to $28^{\circ} \mathrm{C}$, salinity averaged 20.6 $(17-21)$, and DO averaged $6.6 \mathrm{mg} \mathrm{l}^{-1}(2.9-17.5 \mathrm{mg}$ $\left.1^{-1}\right)$.

Sites were muddy sand or oyster reef habitats, with the latter consisting of oyster reef communities that had grown naturally on plastic mesh aquaculture bags containing oysters and placed on racks $(2.4 \mathrm{~m} \times$ $1 \mathrm{~m} \times 0.3 \mathrm{~m})$ adjacent to VIMS $\left(37^{\circ} 14^{\prime} \mathrm{N}, 76^{\circ} 30^{\prime} \mathrm{W}\right)$. These oyster reef communities grew on the tops and sides of the bags and resulted from natural settlement of wild oyster larvae on the bags over a few years. The oyster reef communities developed similar in structure to a natural oyster reef, and consisted of oysters, sponges including red beard Microciona prolifera, mud crabs (Xanthidae), gobies (Gobiidae), striped blennies Chasmodes bosquianus, and feather blennies Hypsoblennius hentz. Three sand sites and 3 oyster sites at least $5 \mathrm{~m}$ apart were chosen haphazardly and marked with PVC poles.

\subsection{Blue crab survival}

Juvenile Callinectes sapidus (10-50 mm CW) of both sexes were collected from the York River, VA, and kept in flow-through tanks. All crabs used in our experiments were immature; blue crabs do not reach sexual maturity until $82 \mathrm{~mm}$ CW for males (Williams 1984) and $90 \mathrm{~mm} \mathrm{CW}$ for females (Van Engel 1958). Crabs were measured, then tethered with $20 \mathrm{~cm}$ lengths of monofilament fishing line by slip knots tightened and secured around the carapace spines of the crab. Monofilament length was shortened from 20 to $12 \mathrm{~cm}$ after the fourth trial to accommodate the field of view of the underwater camera system. This change in tether length did not significantly impact our results, with the short tether trials having a mean $( \pm \mathrm{SE})$ proportional survival of $0.54 \pm 0.16$ and the long tether trials having a mean proportional survival of $0.54 \pm 0.10$. Crabs up to $30 \mathrm{~mm} \mathrm{CW}$ were tethered with $5.4 \mathrm{~kg}$ test monofilament, while crabs measuring $30-50 \mathrm{~mm}$ CW were tethered with $6.8 \mathrm{~kg}$ test monofilament. These test monofilament weights were sufficient to tether the crabs used in this study and not break due to wave action (Heck et al. 2001, Moody 2003, Lipcius et al. 2005). A drop of cyanoacrylate adhesive and a small square of black duct tape were used to secure the knot of the crab tether. Black tape was chosen because it does not reflect light and would not likely attract predators. The monofilament line was then secured to a fishing swivel. Crabs were kept in individual plastic containers with air holes for at least $12 \mathrm{~h}$ in flow-through tanks, to ensure tether retention and crab survival, following methods from previous studies (Lipcius et al. 2005, Johnston \& Lipcius 2012, Bromilow \& Lipcius 2017).

Tethering is a common method to measure relative predation of small benthic species, including crustaceans (Heck \& Wilson 1987, Pile et al. 1996, Hovel \& Lipcius 2001, Moody 2003, Lipcius et al. 2005, Johnston \& Lipcius 2012). Since the ability of tethered animals to escape predation is limited to the length of the tether (Zimmer-Faust et al. 1994), tethering can lead to inflated natural mortality rates. As such, the method can only be used to measure relative rates of predation, not absolute rates. Tethering also has the potential to introduce treatment-specific bias in survival (Peterson \& Black 1994). However, previous studies found no significant interaction between treatment and habitat (Pile et al. 1996, Hovel \& Lipcius 2001, Lipcius et al. 2005); therefore, we assumed there was no treatment-specific bias in our experiments, which used similar tethering methods. 
All tethered crabs were active and had both claws intact. At each sand site, a tethered crab was attached by a swivel to a metal garden stake pushed flush with the bottom. At each oyster habitat site, a zip tie was attached around the oyster rack structure, surrounded by the oyster community, and a tethered crab was attached by swivel to the zip tie (Fig. 1). Tethered crabs had full use of all of their limbs and could bury or hide in their respective habitats. Trials lasted $24 \mathrm{~h}$, with a subset of trials under continuous video surveillance (see details in Section 2.3), at the end of which tethers were pulled up and checked to see if crabs were alive or had been eaten. Following previous studies, a piece of carapace, a chewed line, or a cut line indicated evidence of predation (Bromilow \& Lipcius 2017). Because tethered crabs were held for at least $12 \mathrm{~h}$ prior to deployment, there is high confidence that crabs were not able to cut their line or escape their tether. Some trials did not use video and were only used for assessing survival. Fresh crabs were used at the start of each $24 \mathrm{~h}$ trial. In total, 21 trials were run at sand and oyster sites simultaneously, with 42 crabs tethered at sand sites, and 42 at oyster sites (Fig. 2). Crabs that molted during a trial (3 in oyster trials; 2 in sand trials) were excluded from analyses, resulting in 39 and 40 crabs in the oyster and sand trials, respectively.

\subsection{Predator-prey interactions}

A 4-channel underwater camera system (EverFocus SV-DVC4, Shark Marine Technologies) with
(A)

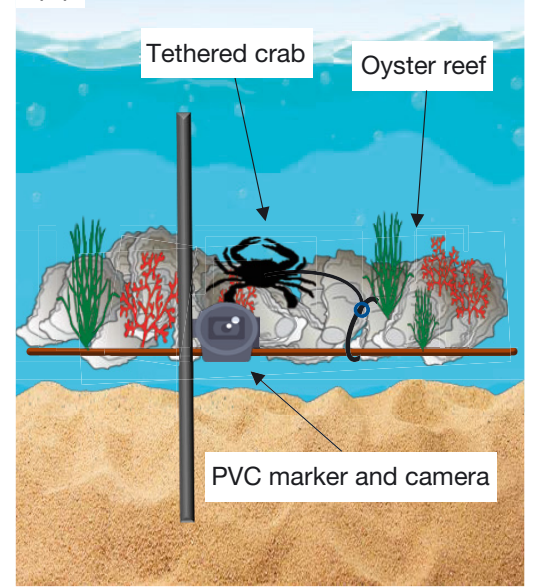

(B)

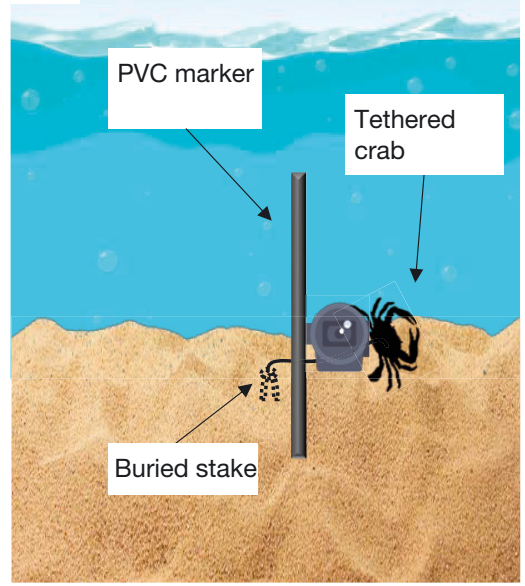

Fig. 1. Tether set-up used in the (A) oyster habitat and (B) sand habitat. The camera was oriented so as to encompass the entire range of the tether. Not drawn to scale

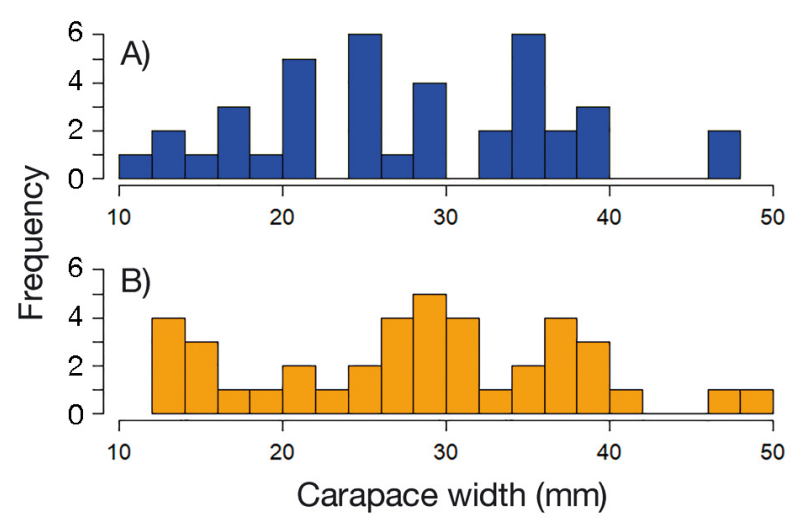

Fig. 2. Distribution of crab carapace width used for tethering in (A) oyster habitat and (B) sand habitat

DVR capabilities (ECOR264-4*1) was utilized to record predation activity for a subset of the $24 \mathrm{~h}$ trials. Recording rate was 30 frames per second. Cameras were positioned on numbered PVC poles at 4 of the 6 sites, such that the entire range of each tethered crab was in the camera's field of view (distance from the crab was 30-40 cm depending on water clarity and habitat type). Low light black and white cameras (SV-14R2) and infrared cameras for night filming (SV-16HR) were used. In total, 47 crabs in 14 trials were recorded (oyster habitat $n=31$, sand habitat $\mathrm{n}=16$ ). Cameras were not used during trials that occurred during stormy weather due to poor visibility. Moreover, predator identification was only attempted in trials where visibility was adequate. Video footage was reviewed by fast forwarding until a predation event occurred and then that segment was analyzed slowly. ET was defined as the time from the start of the trial to the initial predatory interaction between a potential predator and a tethered crab (Gurarie \& Ovaskainen 2013). HT was defined as time (h) from ET to when the prey was eaten, or the time spent feeding on a prey item (Giller 1980).

\subsection{Statistical analyses}

To address the hypotheses regarding juvenile crab survival, we developed 5 statistical models $\left(g_{1}-g_{5}\right)$ following an information-theoretic approach (Burnham \& Anderson 2002, Anderson 2008), including the null model for comparison (Table 1). Each model represented a hypothesis and 
Table 1. Akaike's information criterion (AIC) calculations for logistic regression models corresponding to the different hypotheses for juvenile blue crab survival represented by $g_{i}$. $k$ : number of parameters, including variance $\left(\sigma^{2}\right)$, in model $g_{i i} \mathrm{AIC}_{\mathrm{C}}$ : bias-corrected $\mathrm{AIC}$ value; $\Delta_{i}$ : difference in the $\mathrm{AIC}_{\mathrm{C}}$ value between model $g_{i}$ and the best model $w_{i}$ : probability that model $g_{i}$ is the best model in the set; $\mathrm{CW}$ : crab carapace width; $\mathrm{H}$ : habitat in which juvenile crabs were placed (either sand or oyster reef)

\begin{tabular}{|lcrrrrr|}
\hline Model & Variable(s) & $k$ & $\mathrm{AIC}_{\mathrm{C}}$ & $\Delta_{i}$ & $w_{i}$ & $\begin{array}{c}\% \text { deviance } \\
\text { explained }\end{array}$ \\
\hline $\mathrm{g}_{1}$ & $\mathrm{CW}+\mathrm{H}+(\mathrm{CW} \times \mathrm{H})$ & 4 & 94.51 & 2.54 & 0.13 & 15.6 \\
$\mathrm{~g}_{2}$ & $\mathrm{CW}+\mathrm{H}$ & 3 & 92.39 & 0.42 & 0.39 & 15.4 \\
$\mathrm{~g}_{3}$ & $\mathrm{CW}$ & 2 & 104.63 & 12.66 & $<0.01$ & 1.1 \\
$\mathrm{~g}_{4}$ & $\mathrm{H}$ & 2 & 91.97 & 0.00 & 0.48 & 13.6 \\
$\mathrm{~g}_{5}$ & $\mathrm{Null}$ & 1 & 103.63 & 11.65 & $<0.01$ & - \\
\hline
\end{tabular}

included different combinations of variables that could describe observed differences in the response variables.

Tethered crab survival was modeled as a binary response $(1=$ alive, $0=$ dead $)$, with crab $\mathrm{CW}(\mathrm{mm})$ as a continuous covariate and habitat (oyster, sand) as a fixed factor. Models were analyzed using logistic regression to determine the probability of crab survival, and bias-corrected Akaike's information criterion $\left(\mathrm{AIC}_{\mathrm{C}}\right)$ values were calculated to determine the best model. Weighted model probabilities $\left(w_{i}\right)$ based on $\Delta_{i}$ values were used to determine the probability that a particular model was the best-fitting model. Statistical analyses were conducted using R (R Core Team 2017) and RStudio (version 1.3.1093; RStudio Team 2017) statistical software. Parameter estimates of the best-fitting model were used to calculate binomial survival probabilities as:

$$
\theta=\frac{e^{\alpha+\beta_{1} x_{1}+\beta_{2} x_{2}+\ldots+\beta_{i} x_{i}}}{1+e^{\alpha+\beta_{1} x_{1}+\beta_{2} x_{2}+\ldots+\beta_{i} x_{i}}}
$$

where $\theta$ is the probability of survival, $\alpha$ is the parameter for the baseline condition (constant), and $\beta_{i}$ are parameters representing increases or decreases in survival due to the effect of corresponding independent variables $x_{i}$. Note that interaction terms are represented as $\beta_{i} X_{i} X_{j}$.

\section{RESULTS}

\subsection{Juvenile crab survival}

There was no bias between habitats in the mean CW of crabs used for tethering experiments or for the CW distri- bution of crabs that survived after trials versus crabs that were eaten. The range of crab CW used in the experiments was $13.7-49.1 \mathrm{~mm}($ mean $\pm \mathrm{SE}=$ $28.4 \pm 1.5)$ in sand treatments and $11.6-47.4 \mathrm{~mm}($ mean $=27.7 \pm 1.5)$ in oyster treatments (Fig. 2), and did not differ significantly between treatments (Kolmogorov-Smirnov test, $\mathrm{p}=$ 0.847). The mean $\mathrm{CW}$ for crabs that survived $(\mathrm{n}=27)$ was $29.6 \pm 1.7 \mathrm{~mm}$, whereas the mean CW for crabs eaten during trials $(\mathrm{n}=52)$ was $27.3 \pm$ $1.3 \mathrm{~mm}$, indicating that these mean CWs did not differ significantly due to the overlapping $95 \%$ confidence intervals.

For juvenile crab survival (crabs from both filmed and unfilmed trials), models $\mathrm{g}_{2}$ (habitat and crab CW) and $g_{4}$ (habitat alone) had the highest weighted probabilities, 0.39 and 0.48 , respectively (Table 1). Although model $g_{4}$ had a higher weighted probability, the effect of habitat was nearly equivalent in both models (Table 2), so we interpreted both model $g_{4}$ and model $g_{2}$ to include the effect of crab CW in the results. Models $g_{2}$ and $g_{4}$ both fit the data better than the null model and the global model with an interaction effect (likelihood ratio $\chi^{2}$ test, $p>0.1$ ), and explained 15.4 and $13.6 \%$ of the deviance, respectively. A Stukel test indicated the model fit the data satisfactorily (likelihood ratio $\chi^{2}$ test, $p>0.1$ ). Juvenile crab survival differed significantly between habitats, as indicated by the $95 \%$ confidence interval for the effect of sand habitat in model $g_{4}$ (Table 2). Mean crab survival, calculated from Eq. (1) and parameter estimates in Table 2 for model $g_{4}$, was $53.8 \%$ in oyster habitat, which was over 3 -fold higher than in the sand habitat $(15.0 \%)$.

To assess the joint effects of crab CW and habitat (Fig. 3), parameter estimates of model $g_{2}$ (Table 2)

Table 2. Parameter estimates from logistic regression models $g_{2}$ and $g_{4}$ for juvenile blue crab survival. The sand habitat is compared to the oyster habitat (baseline). CW: carapace width

\begin{tabular}{|c|c|c|c|c|}
\hline Model & Parameter & Estimate & SE & $95 \% \mathrm{CI}$ \\
\hline \multirow[t]{3}{*}{$g_{2}$} & Intercept $=$ oyster reef & -0.905 & 0.862 & $-2.629,0.819$ \\
\hline & CW & 0.038 & 0.029 & $-0.020,0.096$ \\
\hline & Effect of sand habitat & -1.966 & 0.561 & $-3.088,-0.844^{\mathrm{a}}$ \\
\hline \multirow[t]{2}{*}{$g_{4}$} & Intercept $=$ oyster reef & 0.154 & 0.321 & $-0.488,0.796$ \\
\hline & Effect of sand habitat & -1.889 & 0.547 & $-2.983,-0.795^{\mathrm{a}}$ \\
\hline
\end{tabular}




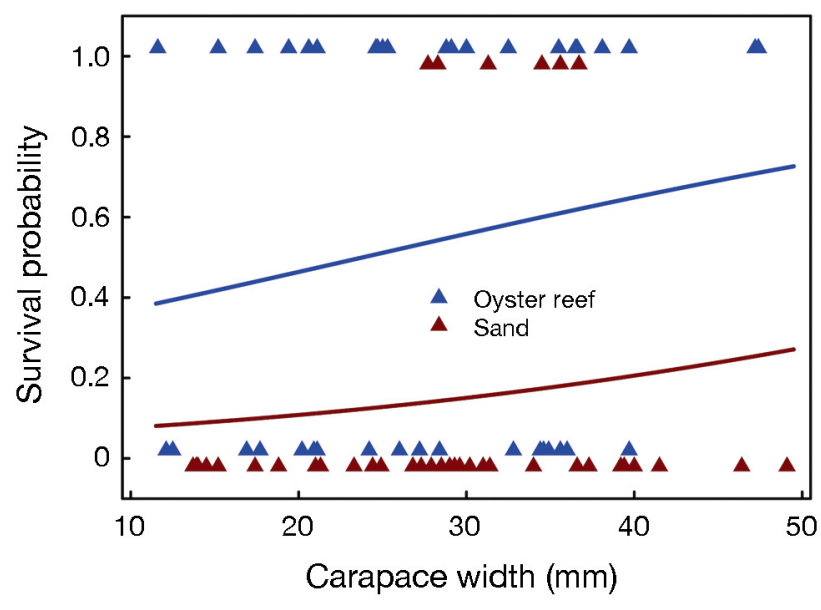

Fig. 3. Crab survival by habitat and carapace width. Eqs. (2) and (3) were used to generate the curves of survival probability

were used to generate survival probabilities using the following equations:

$$
\begin{gathered}
\theta=\frac{e^{-0.905+0.038 x_{1}}}{1+e^{-0.905+0.038 x_{1}}} \\
\theta=\frac{e^{-0.905-1.966+0.038 x_{1}}}{1+e^{-0.905-1.966+0.038 x_{1}}}
\end{gathered}
$$

where $x_{1}=$ crab CW. These represent survival probabilities in oyster habitat (Eq. 2) and sand habitat (Eq. 3), although the estimated effect of crab CW had high variance (Table 2). In oyster reef habitat, survival ranged from $38.5 \%$ for a small $12 \mathrm{~mm}$ CW crab to $72.6 \%$ for a larger $50 \mathrm{~mm} \mathrm{CW} \mathrm{crab}$ (Fig. 3). Conversely, in sand habitat, survival was much lower, ranging from only $8.1 \%$ for a small crab to $27.1 \%$ for a larger juvenile (Fig. 3). To display the disparity in survival probability as a function of $\mathrm{CW}$ in the 2 habitats, we calculated the differences in survival probability between the habitats (cf. Figs. $3 \& 4$ ). The magnitude of the difference in survival probability ranged from 0.30 for small juveniles to 0.46 for larger juveniles (Fig. 4), but the percent difference was inversely related to CW. Oyster reef habitat increased survival probability by almost $400 \%$ for small juveniles but $<200 \%$ for larger juveniles (Fig. 4).

\subsection{Predator identity and behavior}

In total, 47 individual juvenile crabs were filmed, of which 25 had instances of predation that were filmed. Predators were positively identified in 16 instances, with adult blue crabs and the northern pufferfish Sphoeroides maculatus as the most common predators (Table 3, Fig. 5). The range in CW of tethered crabs with filmed instances of predation was $21.1-40.0 \mathrm{~mm}$. The 2 main predators did not have sufficient ETs or HTs in both habitats to permit inter-predator comparisons. Thus, we limited the results to quantitative descriptions of ETs and HTs by habitat.

For ET in the sand habitat, 8 adult blue crabs encountered a tethered crab. Mean $( \pm \mathrm{SE})$ ET was $8.5 \pm$ $2.35 \mathrm{~h}$, with a range of $0.15-16 \mathrm{~h}$. No northern pufferfish encountered tethered crabs in the sand. In the oyster habitat, only 1 adult blue crab encountered a tethered crab, $13 \mathrm{~h}$ after the start of the trial. In contrast, 6 northern pufferfish encountered a tethered crab in oyster habitat. Mean ET was $6.75 \pm 3.0 \mathrm{~h}$, with a range of $1-21 \mathrm{~h}$.

For HT in the sand, all 8 adult blue crab encounters led to consumption over $0.08-0.27 \mathrm{~h}$ with a mean HT of $0.13 \pm 0.02 \mathrm{~h}$. In the oyster habitat, the single adult blue crab consumed the tethered crab in $0.18 \mathrm{~h}$. Meanwhile, all 6 northern pufferfish encounters led to consumption over $0.02-0.37 \mathrm{~h}$ with a mean HT of $0.08 \pm 0.07 \mathrm{~h}$.

Other fish including red drum, black drum, croaker, white perch, and yellow perch were recorded scavenging tethered crab remains, but they never made the initial attack (Table 3). In 1 instance, a blue crab scavenged the remains of a tethered crab eaten

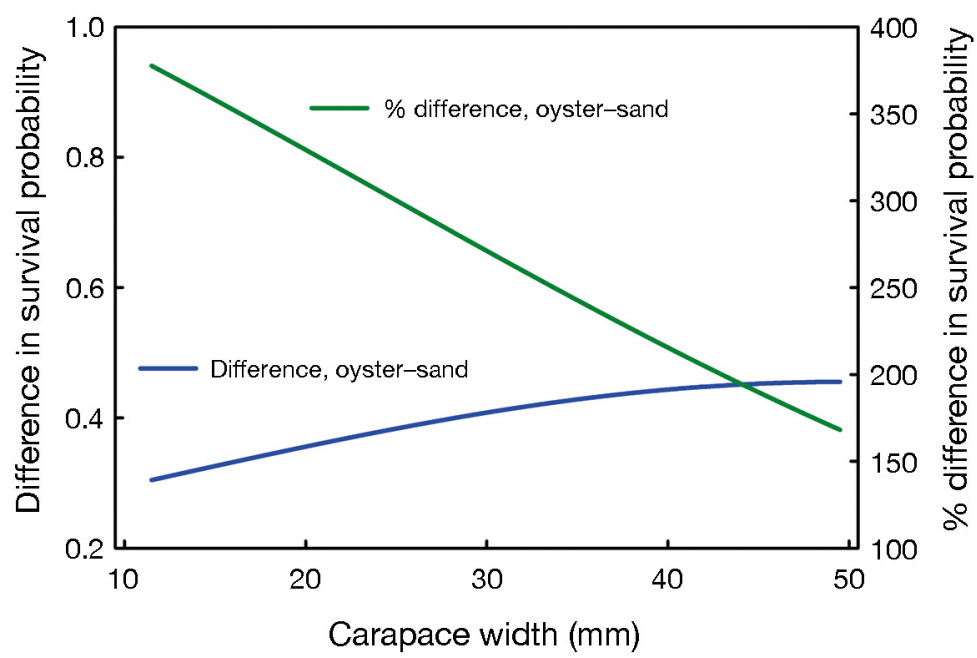

Fig. 4. Difference and percent difference in crab survival probability between oyster habitat and sand habitat. Eqs. (2) and (3) were used to generate the difference in survival probability, and reflect the distance between the curves in Fig. 3. Difference $=$ (Eq. $2-$ Eq. 3)/Eq. 3 either as a magnitude or percent difference 
Table 3. List of predators and scavengers organized by total number of encounters, regardless of consumption. Oyster (sand) habitat encounter: number of times a predator/scavenger encountered a tethered crab in the oyster (sand) habitat; oyster (sand) habitat consumption: number of times a predator/scavenger consumed a tethered crab in the oyster (sand) habitat. Superscripts indicate which scavengers associated with which dominant predator (NP: northern pufferfish BC: blue crab)

\begin{tabular}{|c|c|c|c|c|c|}
\hline Species & $\begin{array}{l}\text { Total } \\
\text { encoun- } \\
\text { ters }\end{array}$ & $\begin{array}{c}\text { Oyster } \\
\text { habitat } \\
\text { encounter }\end{array}$ & $\begin{array}{c}\text { Oyster } \\
\text { habitat } \\
\text { consumption }\end{array}$ & $\begin{array}{c}\text { Sand } \\
\text { habitat } \\
\text { encounter }\end{array}$ & $\begin{array}{c}\text { Sand } \\
\text { habitat } \\
\text { consumption }\end{array}$ \\
\hline \multicolumn{6}{|l|}{ Predators } \\
\hline Blue crab (adult) & 9 & 1 & 1 & 8 & 8 \\
\hline Northern pufferfish & $\operatorname{sh} 6$ & 6 & 6 & 0 & 0 \\
\hline Black seabass & 2 & 2 & 1 & 0 & 0 \\
\hline Oyster toadfish & 1 & 1 & 1 & 0 & 0 \\
\hline \multicolumn{6}{|l|}{ Scavengers } \\
\hline White perch & 3 & $3^{\mathrm{NP}}$ & $3^{\mathrm{NP}}$ & 0 & 0 \\
\hline Croaker & 2 & 0 & 0 & $2^{\mathrm{BC}}$ & $2^{\mathrm{BC}}$ \\
\hline Black drum & 1 & $1^{\mathrm{NP}}$ & $1^{\mathrm{NP}}$ & 0 & 0 \\
\hline Blue crab (adult) & 1 & $1^{\mathrm{NP}}$ & $1^{\mathrm{NP}}$ & 0 & 0 \\
\hline Red drum & 1 & 0 & 0 & $1^{\mathrm{BC}}$ & $1^{\mathrm{BC}}$ \\
\hline Yellow perch & 1 & 0 & 0 & $1^{\mathrm{BC}}$ & $1^{\mathrm{BC}}$ \\
\hline
\end{tabular}

when the crab tether was pulled at the end of an unfilmed trial.

\section{DISCUSSION}

\subsection{Juvenile crab survival}

Survival of juvenile blue crabs was over 3-fold higher in oyster habitat compared to sand. This is the first experimental demonstration of the potential for oyster reefs to serve as nursery habitat that reduces predator-induced mortality for this species. Juvenile crab survival also increased with crab CW, and though not significant, we included crab CW as an independent variable due to the extensive evidence for an effect of blue crab size on survival (Pile et al. 1996, Hovel \& Lipcius 2001, Lipcius et al. 2005, Johnston \& Lipcius 2012, Bromilow \& Lipcius 2017). The positive relationship between survival and crab CW is biologically important because the low survival of the smallest crabs may eliminate them from sand habitats in general (Pile et al. 1996). An ontogenetic shift in habitats has been proposed as a mechanism for blue crabs to improve survival as they grow (Bromilow \& Lipcius 2017), with movement out of structured habitats as crabs grow larger than about $25 \mathrm{~mm}$ CW. The increased survival in structured oyster habitats for juvenile blue crabs is not surprising given the use of other structured nursery habitats by small juvenile crabs (Orth \& van Montfrans 1987, Wilson et al. 1990, Everett \& Ruiz 1993, Hovel \& Lipcius 2001), and use of oyster habitats by other species (Brown et al. 2014). The efficacy of oyster habitats as nurseries for juvenile blue crabs in Chesapeake Bay might depend on the presence of competing species, such as shrimp (Eggleston 1998) and mud crabs, if they deter juvenile blue crabs from using oyster reef as habitat (Grabowski et al. 2008, Hill \& Weissburg 2013). Mud crabs are prevalent in oyster reefs or shelly habitats (Williams 1984, Grabowski et al. 2008). Thus, areas with high densities of mud crabs may preclude use of oyster reefs by small juvenile blue crabs.

The increased survival of juvenile crabs in structured habitats presumably arises from the ability of the crabs to utilize small crevices among and between the structural elements, which protect small by a pufferfish. Two black seabass were recorded attacking a tethered crab, but only one successfully attacked and consumed the tethered crab. One oyster toadfish was caught consuming a tethered crab 
crabs from either being seen or encountered by predators (e.g. Wilson et al. 1990, Pile et al. 1996, Hovel \& Lipcius 2001, Orth \& van Montfrans 2002). The percent increase in crab survival in oyster reef habitat as compared to sand was greatest for small juveniles compared to larger juveniles, suggesting that oyster reefs are most important for the smallest size classes. Our results regarding crab survival agree with our hypothesis and with previous studies showing high juvenile blue crab survival in structured versus unstructured habitats (Lipcius et al. 2007, Bromilow \& Lipcius 2017). Vegetated habitats (i.e. emergent and submerged aquatic vegetation) are presumed to be the primary nursery habitat for juvenile blue crabs in other systems (Heck \& Thoman 1984, Beck et al. 2001, Heck et al. 2003) as well as in Chesapeake Bay (Lipcius et al. 2007). However, the novel demonstration of oyster protection of juvenile blue crabs from predation suggests that restored oyster reefs may serve as alternative nursery habitats, like the exotic red alga Agarophyton vermiculophyllum in Chesapeake Bay (Johnston \& Lipcius 2012) and oyster reefs in the Gulf of Mexico (zu Ermgassen et al. 2021).

\subsection{Predator identity and behavior}

Our video recordings allowed us to identify the main successful predators of juvenile blue crabs in different habitats, with adult blue crabs most common in sand habitats and northern pufferfish most common in oyster habitats. Cannibalism is a wellknown source of mortality for juvenile blue crabs (Dittel et al. 1995, Hines \& Ruiz 1995), but the northern pufferfish was only recently identified as a predator of juvenile blue crabs in video surveys (Moody 2003, Bromilow \& Lipcius 2017). A few other predators were seen in our studies, including red drum, croaker, black seabass, and oyster toadfish, but these were secondary predators and were uncommon.

Blue crabs are olfactory (Weissburg \& Zimmer-Faust 1993) and chemotactile foragers (Lipcius \& Hines 1986, Keller et al. 2003), and they may have been able to detect prey in sand habitat more easily than pufferfish, which likely rely on visual cues since they commonly feed only during the daytime (Strand 2004).

\subsection{Limitations}

We suspect that juvenile blue crab survival on natural, large-scale oyster reefs would be similarly improved as compared to sand habitats, but this needs experimental validation. Furthermore, predator identifications and encounter times were limited at times by poor water clarity in the York River during late summer. Of the 25 videos, 10 were excluded due to poor visibility. Nonetheless, in instances where predators were identified, predators were relatively habitat-specific. Issues with limited visibility could be remedied by replicating the experiment in the spring and late fall when water clarity is typically better but still warm enough for many predators, which may also identify any seasonal differences in predator activity. Finally, juvenile crabs in the midrange size class (20-30 $\mathrm{mm} \mathrm{CW}$ ) were more heavily represented than the smaller and larger size classes (Fig. 2), which may have reduced the statistical power to detect a strong effect of crab size on survival (Pile et al. 1996, Hovel \& Lipcius 2001, Lipcius et al. 2005, Johnston \& Lipcius 2012, Bromilow \& Lipcius 2017). Specifically, we had difficulty catching many crabs in the 40-50 mm CW size class for experiments. However, there was a general continuum of individuals from 10-50 mm CW used in trials for both habitats, and the CW relationship was apparent. Distributing the replicates more evenly would provide a stronger representation of juvenile crab survival and likely strengthen our confidence in the difference in survival by size.

\subsection{Implications}

The value of oyster reefs for supporting survival of juvenile crabs in our system suggests that restoration of oyster reefs could be beneficial for restoring the ecosystem service of providing alternative nursery habitat for juvenile crabs. This increased understanding of the ecosystem value of oyster reefs for blue crabs should help increase success in the economic valuation of ecosystem services provided by oyster reefs (Grabowski et al. 2012). Specifically, this work should increase economic valuation of habitat provisioning related to increased production of mobile fish and invertebrates (Peterson et al. 2003). Future work could focus on examining juvenile blue crab use of large (greater than 1 ha [10000 m²]) restored reefs in the lower Chesapeake Bay (Karp et al. 2018) or natural oyster reefs, to improve our understanding of ecosystem services of restored and natural oyster reef habitats.

Acknowledgements. This research was funded through the National Oceanic and Atmospheric Administration Chesapeake Bay Office, Grant NA14NMF4570288, awarded to R.D.S. and R.N.L. We gratefully acknowledge the assistance 
given by the students and staff of the Community Ecology and Marine Conservation Ecology labs at the Virginia Institute of Marine Science. This paper is contribution number 4024 of the Virginia Institute of Marine Science, William \& Mary.

\section{LITERATURE CITED}

Anderson D (2008) Model based inference in the life sciences: a primer on evidence. Springer Science and Business Media, New York, NY

Baird D, Ulanowicz R (1989) The seasonal dynamics of the Chesapeake Bay ecosystem. Ecol Monogr 59:329-364

*Beck MW, Heck KL, Able KW, Childers DL and others (2001) The identification, conservation and management of estuarine and marine nurseries for fish and invertebrates. Bioscience 51:633-641

Bromilow AM, Lipcius RN (2017) Mechanisms governing ontogenetic habitat shifts: role of trade-offs, predation, and cannibalism for the blue crab. Mar Ecol Prog Ser 584:145-159

Brown LA, Furlong JN, Brown KM, La Peyre MK (2014) Oyster reef restoration in the northern Gulf of Mexico: effect of artificial substrate and age on nekton and benthic macroinvertebrate assemblage use. Restor Ecol 22: 214-222

Burnham KP, Anderson DR (2002) Model selection and multimodel inference: a practical information-theoretic approach, $2^{\text {nd }}$ edn. Springer Science and Business Media, New York, NY

CBNERR (Chesapeake Bay National Estuarine Research Reserve) (2018) VECOS: Virginia Estuarine and Coastal Observing System. http://vecos.vims.edu (accessed 14 May 2020)

Coen LD, Grizzle RE (2007) The importance of habitat created by molluscan shellfish to managed species along the Atlantic coast of the US. Atlantic States Marine Fisheries Commission, Washington, DC

Coen LD, Brumbaugh RD, Bushek D, Grizzle R and others (2007) Ecosystem services related to oyster restoration. Mar Ecol Prog Ser 341:303-307

Dittel A, Hines A, Ruiz G, Gregory M, Ruffin K (1995) Effects of shallow water refuge on behavior and density-dependent mortality of juvenile blue crabs in Chesapeake Bay. Bull Mar Sci 57:902-916

Eggleston DB (1990a) Foraging behavior of the blue crab, Callinectes sapidus, on juvenile oysters Crassostrea virginica: effects of prey density and size. Bull Mar Sci 46: 62-82

Eggleston DB (1990b) Behavioural mechanisms underlying variable functional responses of blue crabs, Callinectes sapidus feeding on juvenile oysters, Crassostrea virginica. J Anim Ecol 59:615-630

Eggleston DB (1990c) Functional responses of blue crabs Callinectes sapidus Rathbun feeding on juvenile oysters Crassostrea virginica (Gmelin): effects of predator sex and size, and prey size. J Exp Mar Biol Ecol 143:73-90

Eggleston DB, Etherington LL, Elis WE (1998) Organism response to habitat patchiness: species and habitatdependent recruitment of decapod crustaceans. J Exp Mar Biol Ecol 223:111-132

Everett RA, Ruiz GM (1993) Coarse woody debris as a refuge from predation in aquatic communities. Oecologia 93:475-486
Giller PS (1980) The control of handling time and its effects on the foraging strategy of a heteropteran predator, Notonecta. J Anim Ecol 49:699-712

* Glaspie CN, Seitz RD (2018) Habitat complexity and benthic predator-prey interactions in Chesapeake Bay. PLOS ONE 13:e0205162

*Grabowski JH (2004) Habitat complexity disrupts predator-prey interactions but not the trophic cascade on oyster reefs. Ecology 85:995-1004

Grabowski JH, Hughes AR, Kimbro DL (2008) Habitat complexity influences cascading effects of multiple predators. Ecology 89:3413-3422

*Grabowski JH, Brumbaugh RD, Conrad RF, Keeler AG and others (2012) Economic valuation of ecosystem services provided by oyster reefs. Bioscience 62:900-909

Gregalis KC, Johnson MW, Powers SP (2009) Restored oyster reef location and design affect responses of resident and transient fish, crab, and shellfish species in Mobile Bay, Alabama. Trans Am Fish Soc 138:314-327

* Gurarie E, Ovaskainen O (2013) Towards a general formalization of encounter rates in ecology. Theor Ecol 6: 189-202

Hassell M (1978) The dynamics of arthropod predator-prey systems. Monogr Popul Biol Vol 13. Princeton University Press, Princeton, NJ

Heck KL, Thoman TA (1984) The nursery role of seagrass meadows in the upper and lower reaches of the Chesapeake Bay. Estuaries 7:70-92

Heck KL Jr, Wilson KA (1987) Predation rates on decapod crustaceans in latitudinally separated seagrass communities: a study of spatial and temporal variation using tethering techniques. J Exp Mar Biol Ecol 107:87-100

Heck KL Jr, Coen LD, Morgan SG (2001) Pre- and post-settlement factors as determinants of juvenile blue crab Callinectes sapidus abundance: results from the northcentral Gulf of Mexico. Mar Ecol Prog Ser 222:163-176

Heck KL Jr, Hays G, Orth RJ (2003) Critical evaluation of the nursery role hypothesis for seagrass meadows. Mar Ecol Prog Ser 253:123-136

Hill JM, Weissburg MJ (2013) Habitat complexity and predator size mediate interactions between intraguild blue crab predators and mud crab prey in oyster reefs. Mar Ecol Prog Ser 488:209-219

Hines A (2007) Ecology of juvenile and adult blue crabs. In: Kennedy VS, Cronin LE (eds) The blue crab, Callinectes sapidus. University of Maryland Sea Grant Press, College Park, MD, p 575-665

Hines A, Ruiz G (1995) Temporal variation in juvenile blue crab mortality: nearshore shallows and cannibalism in Chesapeake Bay. Bull Mar Sci 57:884-901

Holling CS (1959a) The components of predation as revealed by a study of small mammal predation of the European pine sawfly. Can Entomol 91:234-261

Holling CS (1959b) Some characteristics of simple types of predation and parasitism. Can Entomol 91:385-398

*Hovel KA, Lipcius RN (2001) Habitat fragmentation in a seagrass landscape: patch size and complexity control blue crab survival. Ecology 82:1814-1829

Hovel KA, Lipcius RN (2002) Effects of seagrass habitat fragmentation on juvenile blue crab survival and abundance. J Exp Mar Biol Ecol 271:75-98

*Humphries AT, La Peyre MK, Kimball ME, Rozas LP (2011) Testing the effect of habitat structure and complexity on nekton assemblages using experimental oyster reefs. J Exp Mar Biol Ecol 409:172-179 
Johnston CA, Lipcius RN (2012) Exotic macroalga Gracilaria vermiculophylla provides superior nursery habitat for native blue crab in Chesapeake Bay. Mar Ecol Prog Ser 467:137-146

Karp MA, Seitz RD, Fabrizio MC (2018) Faunal communities on restored oyster reefs: effects of habitat complexity and environmental conditions. Mar Ecol Prog Ser 590:35-51

Keller TA, Powell I, Weissburg MJ (2003) Role of olfactory appendages in chemically mediated orientation of blue crabs. Mar Ecol Prog Ser 261:217-231

Lipcius RN, Hines H (1986) Variable functional responses of a marine predator in dissimilar homogeneous microhabitats. Ecology 67:1361-1371

Lipcius R, Latour R (2006) Food web interactions and modeling. In: NOAA Chesapeake Bay Fisheries Ecosystem Advisory Panel (ed) Fisheries ecosystem planning for the Chesapeake Bay. Trends in fisheries science and management 3. American Fisheries Society, Bethesda, MD, p 91-128

Lipcius R, Van Engel W (1990) Blue crab population dynamics in Chesapeake Bay: variation in abundance (York River 1972-1988) and stock-recruit functions. Bull Mar Sci 46:180-194

Lipcius RN, Eggleston DB, Miller DL, Luhrs TC (1998) The habitat-survival function for Caribbean spiny lobster: an inverted size effect and non-linearity in mixed algal and seagrass habitats. Mar Freshw Res 49:807-816

Kipcius RN, Seitz RD, Seebo MS, Colón-Carrión D (2005) Density, abundance and survival of the blue crab in seagrass and unstructured salt marsh nurseries of Chesapeake Bay. J Exp Mar Biol Ecol 319:69-80

Lipcius R, Eggleston D, Heck K, Seitz R, van Montfrans J (2007) Ecology of postlarval and young juvenile blue crabs. In: Kennedy VS, Cronin LE (eds) The blue crab, Callinectes sapidus. University of Maryland Sea Grant Press, College Park, MD, p 535-564

Mansour RA (1992) Foraging ecology of the blue crab, Callinectes sapidus Rathbun, in lower Chesapeake Bay. PhD dissertation, College of William and Mary, Williamsburg, VA

Meise CJ, Stehlik LL (2003) Habitat use, temporal abundance variability, and diet of blue crabs from a New Jersey estuarine system. Estuaries 26:731-745

Meyer DL, Townsend EC (2000) Faunal utilization of created intertidal eastern oyster (Crassostrea virginica) reefs in the southeastern United States. Estuaries 23: $34-45$

Minello TJ, Able KW, Weinstein MP, Hays CG (2003) Salt marshes as nurseries for nekton: testing hypotheses on density, growth and survival through meta-analysis. Mar Ecol Prog Ser 246:39-59

Moksnes PO, Lipcius RN, Pihl L, van Montfrans J (1997) Cannibal-prey dynamics in young juveniles and postlarvae of the blue crab. J Exp Mar Biol Ecol 215:157-187

Moody KE (2003) Predators of juvenile blue crabs outside of refuge habitats in lower Chesapeake Bay. Estuaries 26: 759-764

NOAA (National Oceanic and Atmospheric Administration) (2019) Landings. https://foss.nmfs.noaa.gov/apexfoss/f? $\mathrm{p}=215: 200: 1228787575241:: \mathrm{NO}:::$

* Orth RJ, van Montfrans J (1987) Utilization of a seagrass meadow and tidal marsh creek by blue crabs Callinectes sapidus. I. Seasonal and annual variations in abundance with emphasis on post-settlement juveniles. Mar Ecol Prog Ser 41:283-294
Orth RJ, van Montfrans J (2002) Habitat quality and prey size as determinants of survival in post-larval and early juvenile instars of the blue crab Callinectes sapidus. Mar Ecol Prog Ser 231:205-213

Peterson CH, Black R (1994) An experimentalist's challenge: when artifacts of intervention interact with treatments. Mar Ecol Prog Ser 111:289-297

* Peterson CH, Grabowski JH, Powers SP (2003) Estimated enhancement of fish production resulting from restoring oyster reef habitat: quantitative valuation. Mar Ecol Prog Ser 264:249-264

* Pfirrmann BW, Seitz RD (2019) Ecosystem services of restored oyster reefs in a Chesapeake Bay tributary: abundance and foraging of estuarine fishes. Mar Ecol Prog Ser 628:155-169

* Pile AJ, Lipcius RN, van Montfrans J, Orth RJ (1996) Density-dependent settler-recruit-juvenile relationships in blue crabs. Ecol Monogr 66:277-300

Plunket J, LaPeyre M (2005) Oyster beds as fish and macroinvertebrate habitat in Barataria Bay, Louisiana. Bull Mar Sci 77:155-164

Posey M, Alphin T, Powell C (1999) Use of oyster reefs as habitat for epibenthic fish and decapods. In: Luckenbach M, Mann R, Wesson J (eds) Oyster reef habitat restoration: a synopsis and synthesis of approaches. Virginia Institute of Marine Science Press, Gloucester Point, VA, p 229-237

R Core Team (2017) R: a language and environment for statistical computing. R Foundation for Statistical Computing, Vienna

Ralph GM, Seitz RD, Orth RJ, Knick KE, Lipcius RN (2013) Broad-scale association between seagrass cover and juvenile blue crab density in Chesapeake Bay. Mar Ecol Prog Ser 488:51-63

* Robillard M, Stunz G, Simons J (2010) Relative value of deep subtidal oyster reefs to other estuarine habitat types using a novel sampling method. J Shellfish Res 29: 291-302

* Rodney WS, Paynter KT (2006) Comparisons of macrofaunal assemblages on restored and non-restored oyster reefs in mesohaline regions of Chesapeake Bay in Maryland. J Exp Mar Biol Ecol 335:39-51

RStudio Team (2017) RStudio: integrated development environment for R. RStudio, Boston, MA

* Seitz RD, Ewers Lewis CJ (2018) Loss of seagrass results in changes to benthic infaunal community structure and decreased secondary production. Bull Mar Sci 94:1273-1292

Seitz RD, Lipcius RN, Hines AH, Eggleston DB (2001) Density-dependent predation, habitat variation, and the persistence of marine bivalve prey. Ecology 82:2435-2451

Seitz RD, Lipcius RN, Seebo MS (2005) Food availability and growth of the blue crab in seagrass and unvegetated nurseries of Chesapeake Bay. J Exp Mar Biol Ecol 319: 57-68

พ Shervette VR, Gelwick F, Hadley N (2011) Decapod utilization of adjacent oyster, vegetated marsh, and nonvegetated bottom habitats in a Gulf of Mexico estuary. J Crustac Biol 31:660-667

Sih A, Crowley P, McPeek M, Petranka J, Strohmeier K (1985) Predation, competition, and prey communities: a review of field experiments. Annu Rev Ecol Syst 16: 269-311

Sponaugle S, Lawton P (1990) Portunid crab predation on juvenile hard clams: effects of substrate type and prey density. Mar Ecol Prog Ser 67:43-53 
Stehlik LL, Pikanowski RA, McMillan DG (2004) The Hudson-Raritan estuary as a crossroads for distribution of blue (Callinectes sapidus), lady (Ovalipes ocellatus), and Atlantic rock (Cancer irroratus) crabs. Fish Bull 102: 693-710

Stoner AW (2009) Habitat-mediated survival of newly settled red king crab in the presence of a predatory fish: role of habitat complexity and heterogeneity. J Exp Mar Biol Ecol 382:54-60

Strand $\varnothing$ (2004) Fish predation studies. In: Nadeau M, Tita G (eds) Atelier de travail 'Prédation du pétoncle et gestion des ensemencements'. Compte Rendu 24. Ministère de l'Agriculture, des Pêcheries et de l'Alimentation du Québec (MAPAQ), Gaspé, p 20-22

Thomas J, Zimmerman R, Minello T (1990) Abundance patterns of juvenile blue crabs (Callinectes sapidus) in nursery habitats of two Texas bays. Bull Mar Sci 46:115-125

Van Engel WA (1958) The blue crab and its fishery in the Chesapeake Bay. Part 1. Reproduction, early development, growth, and migration. Commer Fish Rev 20:6-17

Weissburg MJ, Zimmer-Faust RK (1993) Life and death in moving fluids: hydrodynamic effects on chemosensorymediated predation. Ecology 74:1428-1443

Editorial responsibility: Jana Davis,

Annapolis, Maryland, USA

Reviewed by: A. van den Brink, R. Glazner and 2 anonymous referees
Wilber DH, Hadley NH, Clarke DG (2012) Resident crab associations with sedimentation on restored intertidal oyster reefs in South Carolina and the implications for secondary consumers. N Am J Fish Manag 32:838-847

Williams A (1984) Shrimps, lobsters, and crabs of the Atlantic coast of the eastern United States, Maine to Florida. Smithsonian Institution Press, Washington, DC

WWilson KA, Able KW, Heck KL Jr (1990) Predation rates on juvenile blue crabs in estuarine nursery habitats: evidence for the importance of macroalgae (Ulva lactuca). Mar Ecol Prog Ser 58:243-251

* Yeager LA, Layman CA (2011) Energy flow to two abundant consumers in a subtropical oyster reef food web. Aquat Ecol 45:267-277

Zimmer-Faust RK, Fielder DR, Heck KL Jr, Coen LD, Morgan SG (1994) Effects of tethering on predatory escape by juvenile blue crabs. Mar Ecol Prog Ser 111:299-303

Zu Ermgassen PS, DeAngelis B, Gair JR, Zu Ermgassen S and others (2021) Estimating and applying fish and invertebrate density and production enhancement from seagrass, salt marsh edge, and oyster reef nursery habitats in the Gulf of Mexico. Estuaries Coasts 44: 1588-1603

Submitted: September 14, 2020

Accepted: June 3, 2021

Proofs received from author(s): August 13, 2021 